\title{
The cooperation agreements within the belt and road initiative: The european common commercial policy at crossroads
}

\author{
Los acuerdos de cooperación en el marco de la nueva ruta de la seda: \\ la política comercial común europea en jaque
}

\author{
Carmen Martínez San Millán \\ PhD Student \\ International Law and International Relations \\ University of Valladolid \\ cmartinez@uva.es
}

doi: http://dx.doi.org/10.18543/ced-03-2022pp51-69

Recibido el 10 de mayo de 2021

Aceptado el 5 de noviembre de 2021

Summary: I. Introduction.-II. The cooperation agreements within the Belt and Road Initiative: violation of European Union Law? 1. The Belt and Road Initiative. 2. The European Union Member States' Memorandums of Understanding. 3. Incompatibility of the Memorandums of Understanding with European Union Law.-III. The crash between these Memorandums of Understanding and the European Common Commercial Policy 1. The Free Trade Agreements within the European Common Commercial Policy. 2. Are these Memorandums of Understanding Free Trade Agreements? 3. What can the European Union do?-IV. Conclusion.

\begin{abstract}
To carry out Chinese investments in third countries under the Belt and Road Initiative, the China is currently concluding numerous cooperation agreements called Memorandums of Understanding with its objective States, including European Union Member States. These Memorandums of Understanding are international agreements, but not international treaties as such, which implies that these documents may not lead to rights and obligations under International Law. However, every Memorandum of Understanding signed between China and a European Member States should be interpreted in accordance with European Law. The problem is that Member States are presumably violating different instruments of this legal framework as well as the European Union Common Commercial Policy, which is an exclusive competence of this international organization, if we interpret that these cooperation agreements are masking free trade agreements. This paper aims to analyse this possible interpretation and its consequences for the European Union, as these agreements entail a weakening of the European trade and investment power and put the European Common Commercial Policy at crossroads.
\end{abstract}


Keywords: Belt and Road Initiative, Memorandums of Understanding, European Union, Common Commercial Policy, Trade Power.

Resumen: Para llevar a cabo las inversiones que China tiene planeadas en terceros países en el marco de la Nueva Ruta de la Seda, el Gigante Asiático está celebrando actualmente numerosos acuerdos de cooperación denominados Memorandos de Entendimiento con sus Estados objetivo, incluidos algunos Estados Miembros de la Unión Europea. Estos Memorandos de Entendimiento son acuerdos internacionales, pero no tratados internacionales como tales, lo que implica que estos instrumentos pueden no pueden contener derechos y obligaciones propias del Derecho Internacional. Sin embargo, todo Memorando de Entendimiento concluido entre China y un Estado Miembro de la Unión debe interpretarse de acuerdo con el Derecho de la Unión Europea. El problema es que los Estados Miembros están presuntamente violando diferentes instrumentos de este marco normativo, así como la Política Comercial Común de la Unión Europea, que es competencia exclusiva de esta organización internacional, si interpretamos que estos acuerdos de cooperación están enmascarando acuerdos de libre comercio. Este artículo tiene como objetivo analizar esta posible interpretación y sus consecuencias para la Unión Europea, ya que estos acuerdos suponen un debilitamiento del poder comercial e inversor europeo y sitúan la Política Comercial Común Europea en jaque.

Palabras clave: Nueva Ruta de la Seda, Memorandos de Entendimiento, Unión Europea, Política Comercial Común, Poder Comercial. 


\section{Introduction}

The European Union (EU) is an international organization with an integrational character to which its Member States have cede the exercise of exclusive sovereign powers in various areas, including common commercial policy. In this way, the Union, in accordance with the provisions of articles 206 and 207 of the TFEU, is in charge of changes in tariff rates, the conclusion of tariff and trade agreements relating to trade in goods and services, and the commercial aspects of intellectual property, foreign direct investment, the achievement of uniformity in measures of liberalisation, export policy and measures to protect trade ${ }^{1}$. One of the ways through which the EU materializes these trade relations with third countries and trade organizations is the negotiation and conclusion of free trade agreements, which are international treaties that are guided by the principles of the multilateral trade system and the legal framework of EU.

Nevertheless, some Member States are currently challenging this exclusive competence of the EU in trade matters by signing bilateral cooperation agreements that include trade provisions with China under the Belt and Road Initiative (BRI), a geostrategic plan of the Chinese Government to promote the creation of infrastructures that connect both regions of the world through different investment projects in order to create synergies and improve the use of international trade. Hungary was the first EU Member State that signed a cooperation agreement with China, followed by other eastern countries like Poland and Czech Republic. Regarding other EU Member States, the Greek government is the leading supporter of the BRI in the Mediterranean Sea, and the Italian government has been the first G7 country to formally join the Initiative on 23 March, 2019 , constituting an important context change that has raised alarms within the EU and generated important tensions. On the contrary, northern and western EU Member States, such as France or Germany, remain loyal to the European Commission and publicly reject the BRI.

Although it has already been stated that these bilateral cooperation agreements, called Memorandums of Understanding (MoUs), already constitute a violation of some of the instruments and principles of EU Law, such as the loyal cooperation principle or the Council Decision of 22 July 1974 establishing a consultation procedure for cooperation agreements between Member States and third countries, to determine whether or not these MoUs are violating the European Common Commercial Policy

${ }^{1}$ Consolidated version of the Treaty on the Functioning of the European Union (OJ C 326, 26th October, 2012). 
(ECCP), a deeper interpretive study of them is necessary. As we will have the opportunity to verify in this paper, with an extensive interpretation it is possible to argue that the MoUs concluded between some EU Member States with China represent a de facto violation of European Law, although not a de jure violation. In this context, it is worth asking, therefore, what tools does the Union have to deal with this possible infringement.

Finally, as we will see, although the aforementioned violation of the ECCP may be debatable, what raises no doubt is the current weakening of the EU trade and investment power as consequence.

\section{The cooperation agreements within the Belt and Road Initiative: violation of EU Law?}

Before introducing ourselves into the interpretation of the MoUs concluded between China and some EU Member States, it is necessary to offer some basic information on the BRI to understand what this universal Chinese project entails, as well as to analyse the legal nature of this series of MoUs and its current incompatibility with some principles and instruments of EU Law in order to subsequently delve into the study of its possible conflict with the ECCP and its consequences.

\section{The Belt and Road Initiative}

The "Chinese dream" is the doctrine understood as the rejuvenation of the Chinese nation and the impulse of a strong country, where citizens experience a considerable improvement in their quality of life $^{2}$. This doctrine has been promoted by Xi Jinping since his election as General Secretary of the Communist Party of China on November 2012 and due to this conception, China has managed to change its perception abroad from one of the world's factory to one of the world's powers, focused on expanding its influence in other countries. To achieve this makeover, the Beijing government has implemented different policies and strategies, such as the one called "Made in China 2025" to promote and restructure its industry with which China aims to be a leader in technology on an international scale, or the Ban on the import of plastic waste in January 2018.

${ }^{2}$ Xulio Ríos, «The Belt and Road Initiative: An Opportunity for Spain», Sinología Hispánica, China Studies Review 6, n. ${ }^{\circ} 1$ (2018): 162. David Arase, «Trends in Southeast Asia. The geopolitics of Xi Jinping's Chinese dream: problems and prospects», ISEAS-Yusof Ishak Institute 15 (2016): 6. 
However, the most impressive plan to date is the BRI, which aims to create a global infrastructure through a series of investment projects mainly focusing on building transport and energy infrastructure that facilitates access to more efficient routes and to a decrease in the cost of international trade. Besides, this plan allows China to take advantage of the natural resources located in third countries, to expand China's influence abroad and to increase its national economic growth.

The originally called "One Belt, One Road"3, nowadays called BRI, was announced by President Xi Jinping in an diplomatic visit to Kazakhstan on September $2013^{4}$ and it consist of a plan to promote policy coordination, infrastructure connection, trade facilitation, financial integration, industrial cooperation and mutual understanding among peoples ${ }^{5}$. In some authors' words, the prime aim of this Initiative is "to boost economic and political relations with neighbouring countries"6. The use of trade, investment and finances to support strategic interests is called economic diplomacy and China makes good use of it to achieve its external objectives in the medium and long term and to consolidate itself as a global power.

Technically speaking, the BRI consists of two main routes: a land route, known as the Silk Road Economic Belt, and a sea route, called the 21st-Century Maritime Silk Road ${ }^{7}$. Besides, the Initiative has six principal corridors that have shown different degrees of development in recent years: China-Pakistan; New Eurasian Land Bridge; China-Central Asia-Western Asia; China-Mongolia-Russia; China-Indochina Peninsula; BangladeshChina-India-Myanmar ${ }^{8}$.

3 Antonio Alonso, «Los intereses de China en Asia Central, Belt and Road». Revista UNISCI 45 (2017): 70, DOI: http://dx.doi.org/10.5209/RUNI.57284

4 The place for the announcement was premeditated, as this Central Asia region is vital for the Initiative.

Bruno De Conti, Marina Sequetto Pereira and Daniela Magalhães Prates, «Belt and Road Initiative: A Chinese Marshall plan?», Papel Político 24, n. ${ }^{\circ} 2$ (2019): 5, DOI: https://doi. org/10.11144/Javeriana.papo24-2.bric

5 As defined by the Oficina del Grupo Dirigente para el Fomento de la Construcción de la Franja y la Ruta, within the China's Embassy in Uruguay. Available in: http:// uy.china-embassy.org/esp/xwdts/t1675198.htm

6 Justyna Misiągiewicz and Marcin Misiągiewicz, «China's "One Belt, One Road” initiative - the perspective of the EU», Annales Universitatis Mariae Curie-Skłodowska, Sectio KPolitologia 23, n. 1 (2016): 34, DOI:10.17951/k.2016.23.1.33.

7 Alonso, «Los intereses...»,72. De Conti, «Belt...», 5. Virginia Soledad Busilli, «Belt and Road Initiative (BRI): la iniciativa estratégica de Xi Jinping», Cuadernos de Política Exterior Argentina (Nueva Época) 131 (2020): 75.

8 Busilli, «Belt...», 77. Anastas Vangeli, «China's Engagement with the Sixteen Countries of Central, East and Southeast Europe under the Belt and Road Initiative», China and World Economy 25, n. ${ }^{\circ} 5$ (2017): 104, DOI: 10.1111/cwe.12216. 
To finance the infrastructure necessary to create such routes and corridors and increase connectivity, China created a Silk Road Funds and the Asian Infrastructure Investment Bank, launched in December $2015^{9}$. The goal is to reach 1 trillion US\$ investment funds to finance the infrastructure projects, which turns the BRI into "the most impressive infrastructure plan in history" 10 , even more than the Marshall Plan, to which it has been compared by some authors ${ }^{11}$.

Regarding the partners involved in the Initiative, the countries that take part of this BRI are wide and heterogeneous in nature. It is interesting to mention the participation of Russia, as it constitutes the reaffirmation of the geostrategic coalition against the United States. Moreover, the participation of EU Member States is also important in geostrategic terms, as we will analyse later. However, there are two significant absences: United States, for obvious reasons, and Japan, as this country is an historical United States' allied ${ }^{12}$. In addition to the sovereign States, in the BRI also international organizations participate, such as the United Nations or the African Union, evidencing the China's need to develop regional approaches towards cooperation ${ }^{13}$. Finally, international actors such as NGOs, multinational enterprises and think tanks are also welcomed in the Initiative ${ }^{14}$.

The most important thing that we must keep in mind is that this BRI is not a multilateral project governed by a multilateral international treaty, nor an international organization, but a bilateral strategy, as the extensive network of international relations between China and its partners is formalized through bilateral cooperation agreements, called Memorandums of Understanding, that contains provisions related to trade. In this way, China manages to modulate its interests based on the partner with whom it negotiates.

\section{The EU Member States' Memorandums of Understanding}

To discuss whether these cooperation agreements that include trade matters signed between China and some EU Member States are incom-

9 Alonso, «Los intereses...»,71. De Conti, «Belt...», 6 .

${ }^{10}$ De Conti, «Belt...», 6 .

11 Zhao Minghao, «The Belt and Road Initiative and its Implications for China-Europe Relations», International Spectator: Italian Journal of International Affairs 51, n. ${ }^{\circ} 4$ (2016): 114, DOI: 10.1080/03932729.2016.1235819

12 Busilli, «Belt...», 82 .

13 Vangeli, «China's...», 103.

14 Busilli, «Belt...», 80 . 
patible with the ECCP or not, first, it is important to analyse the legal nature of these agreements and, second, the reasons why some EU Member States have signed this kind of cooperation agreements with China.

MoUs are international agreements, but not international treaties as such, as defined in article 2.1.a) of the Vienna Convention on the Law of the Treaties ${ }^{15}$, which implies that these agreements do not contain rights and obligations subject to International Law, falling, then, within the scope of soft-law, that is, "those non-binding rules or instruments that interpret or inform our understanding of binding legal rules or represent promises that in turn create expectations about future conduct" 16 . Thus, soft-law is half way between fully binding international treaties and fully political positions. Nevertheless, this lack of legal enforcement does not imply lack of legal implications, as Guzman and Meyes affirms, because soft-law shape States' expectations as to what constitutes compliant behaviour ${ }^{17}$.

This way, sovereign States sign MoUs instead of international treaties to coordinate their behaviour and to avoid the cost of violation ${ }^{18}$. If China and EU Member States concluded international treaties instead of MoUs, these international treaties would be governed by International Law (art. 2.1.a) of the Vienna Convention), including the European Law in force.

As for the EU Member States that have signed this kind of agreements, China is aware of the reluctance of some European countries and the EU itself to do business with it due to its economic structure and poor transparency ${ }^{19}$. Because of this reason, the Beijing Government is focusing on finding allies with respect to which China can retain its negotiating power and win the balance. These allies include countries dissatisfied with the EU integration process, such as Hungary, which was the first EU Member State that signed a $\mathrm{MoU}$ with $\mathrm{China}^{20}$, followed by other eastern countries like

15 Article 2.1.a) of the Vienna Convention on the Law of the Treaties defines international treaties as "an international agreement concluded between States in written form and governed by International Law, whether embodied in a single instrument or in two or more related instruments and whatever its particular designation". Vienna Convention on the Law of Treaties, done at Vienna on 23 May 1969. Entered into force on 27 January 1980. United Nations, Treaty Series (Vol. 1155, 331).

16 Andrew T. Guzman and Timothy L. Meyer, «International Soft Law», Journal of Legal Analysis 2, n..$^{\circ}$ (2010): 174.

17 Guzman and Meyer, «International...», 175.

18 Guzman and Meyer, «International...», 168 and 175.

19 European Commission, «EU-China - A strategic outlook», 2019. Available in: https:// ec.europa.eu/info/sites/info/files/communication-eu-china-a-strategic-outlook.pdf

20 Minghao, «The Belt...», 113. 
Poland and Czech Republic ${ }^{21}$. The main reason for these countries to support the BRI is the reaffirmation of their sovereignty in foreign affairs ${ }^{22}$. Within the southern and Mediterranean EU Member States, Greece is the main supporter of the BRI, having signed a MoU with China in 2017. However, a more recent event that has supposed a paradigm shift has been the conclusion of a MoU between Italy and China on 23 March, 2019, transforming Italy into the first G7 country to formally join the BRI and causing significant tensions within EU ${ }^{23}$. Finally, within the northern and western EU Member States, captained by France and Germany, there is a strong oppose towards the BRI, thus supporting the EU point of view. As we can see, the stance of EU Member States on the BRI is "far from being homogeneous" ${ }^{24}$ because while some EU Member States have refused to be part of the initiative, others have enthusiastically joined it.

\section{Incompatibility of the Memorandums of Understanding with EU Law}

Although MoUs, as cooperation agreements, are not international treaties as defined by the article 2.1.a) of the Vienna Convention on the Law of Treaties and, therefore, they are not governed by International Law, we must keep in mind that the EU is one of the few international organizations with an integrational nature and the European legal framework is a sui generis Law, which goes beyond simple cooperation between sovereign States. According to the article 3 of TFEU ${ }^{25}$, this organization shall have exclusive competence in different matter such as

${ }^{21}$ It is important to note that these three EU Member States, Hungary, Poland and Czech Republic, have been subject to infringement procedures by the European Commission due to their refusal to host asylum seekers. Pagán, «Internal...», 13.

22 Antonio José Pagán Sánchez, «Internal tensions and economic opportunities: explaining the heterogeneous stance of EU Member States towards the Belt and Road Initiative», Revista Electrónica de Estudios Internacionales 40 (2020): 12. DOI: 10.17103/reei.40.13

${ }^{23}$ Femke Van der Eijk and Angela Pandita Gunavardana, 25th June, 2019, «The Road that divided the EU: Italy joins China's Belt and Road Initiative», European Law Blog. Available in, https://europeanlawblog.eu/2019/06/25/the-road-that-divided-the-euitaly-joins-chinas-belt-and-road-initiative/ (last accessed: May 5, 2021).

However, it should be noted that the signing of this agreement took place in a context of political instability in Italy, with Giuseppe Conte at the helm, that led to the return of technocracy. In February 2021, Mario Dragui, a self-confessed Europeanist, was elected president of the council of ministers and, therefore, the current technocratic configuration of the Italian executive may be able to contain the potential negative effects of such an agreement for the ECCP.

24 Pagán, «Internal...», 15.

${ }^{25}$ Consolidated version of the Treaty on the Functioning of the European Union (OJ C 326, 26th October, 2012). 
custom union, monetary policy and common commercial policy with third countries, among others. This implies that EU Member States have ceded the exercise of these competences to the Union itself and must refrain from exercising them. However, there are other sovereign competences in traderelated issues that remain in the hands of the States like the negotiation and conclusion of cooperation agreements with third countries other than free trade agreements, here called MoUs.

Nonetheless, the possibility of concluding MoUs by the EU Member States with third countries is still subject to the fulfilment of European legal instruments and principles to avoid disloyalty and improve the cohesion of the different state and European policies.

One of these principles is contained in article 4.3 of the Treaty on EU, which states "the Member States shall facilitate the achievement of the Union's tasks and refrain from any measure which could jeopardise the attainment of the Union's objectives" 26 . This principle is known as "loyal cooperation principle" 27 . Given that the EU has concluded in principle the negotiations on the Comprehensive Agreement on Investment (CAI) and is in its trade agenda objectives to negotiate a free trade agreement with China, bilateral MoUs that foreseen trade issues between this country and EU Member States may seem incompatible with article 4.3 of the Treaty on the EU, as they can jeopardise the attainment of the Union's objectives.

Regarding the legal instruments that EU Member States still have to comply with when signing MoUs with China, it is important to mention the European Council Decision of 22th July 1974, establishing a consultation procedure for cooperation agreements between Member States and third countries $^{28}$. In this instrument, the Council, although ensured in the preamble that these cooperation agreements are "in accordance with the common policies, and with the common commercial policy in particular", established a consultation procedure for cooperation agreements between Member States and third countries "to ensure that the agreements (...) are consistent with common policies and in particular the common commercial policy; to facilitate the exchange of information and views in order to identify problems of common interest and, in view of these, to encourage coordination, where appropriate, of the activities of the Member States with regard to the third countries concerned; and to examine the advisability of unilateral measures which could be taken by the Community (...) in order

\footnotetext{
${ }^{26}$ Consolidated version of the Treaty on the EU (OJ C 326, 26th October, 2012).

27 Luciana Bezerita, «Infringement procedure - The case of Romania», Internal Auditing and Risk Management 4, n. 60 (2020): 702.

${ }^{28}$ Council Decision of 22th July, 1974, establishing a consultation procedure for cooperation agreements between Member States and third countries (OJ L 208, 30th July, 1974).
} 
to promote cooperation projects" ${ }^{29}$. Specifically, this Decision states "Member States shall inform the Commission and the other Member States of agreements relating to economic and industrial cooperation which they propose to negotiate or renew with third countries and of commitments and measures which are proposed by the authorities of the Member States concerned as part of cooperation agreements and which may affect the common policies, and in particular of those which may affect trade" 30 . The main problem is that, according to the European Commission, as included in a recent European Court of Auditor's Report ${ }^{31}$, they have not been informed about any MoUs signed by Member States, thus violating the 1974 Decision and, therefore, EU Law in force.

As we can see, there is little to argue about these legal incompatibilities. However, to study the possible incompatibility of these MoUs with the ECCP and to analyse what the Union can do about it, a more indepth analysis is necessary.

\section{The crash between these Memorandums of Understanding and the European Common Commercial Policy}

Having analysed some incompatibilities between the MoUs signed by EU Member States with China and the European legal framework in force, it is time to lift the latch of a deeper debate: are these MoUs masking typical dispositions included in free trade agreements? Can it be argued that these MoUs can be considered free trade agreements? If so, are EU Member States violating the Common Commercial Policy as an exclusive competence of the EU? What can the EU do to restore the legality?

\section{The Free Trade Agreements within the European Common Commercial Policy}

The article 21.2.e) of the Treaty on EU establishes the duty to define and implement common policies and actions, as well as to strive to achieve a high degree of cooperation in all areas of international relations, in order "to promote the integration of all countries in the world economy" with

29 Article 3 of the Council Decision of 22th July, 1974.

30 Article 1 of the Council Decision of 22th July, 1974.

${ }^{31}$ European Court of Auditors, «The EU's response to China's state-driven investment strategy», Review n. ${ }^{\circ}$ 3, p. 45. Available in: https://www.eca.europa.eu/Lists/ECADocuments/ RW20_03/RW_EU_response_to_China_EN.pdf (last accessed: May 5, 2021). 
measures such as the progressive elimination of obstacles to international trade. One of the most important common policies, together with the Development Cooperation Policy or the Common Foreign and Security Policy, is the ECCP, which was already included in the 1957 Treaty of Rome and whose legal basis, at present, is found in articles 206 and 207 of the TFEU, where said Common Commercial Policy appears developed although without enjoying an exhaustive definition.

Regarding the nature of the Common Commercial Policy, as stated before, we are facing a matter in which the EU has exclusive competence, as stablished in article 3 of the TFEU and reaffirmed in the ruling of December 13, 1973, in which the European Court of Justice recognized incidentally, "the adoption of this common commercial policy falls within the exclusive jurisdiction of the Community" 32 , and in the Opinion 1/75 in response to the request made by the European Commission on the competence of the European Community to conclude within the framework of the Organization for Economic Cooperation and Development an agreement on certain issues related to export credit, which concluded that a parallel competence of the Member States and the European Community in matters of trade policy was inadmissible because any unilateral action on the part of the Member States would lead to disparities in the conditions for the grant of export credits, calculated to distort competition between undertakings of the various Member States in external markets"33. Consequently, this exclusivity eliminates any possibility of state intervention in the Union's trade policy ${ }^{34}$.

Finally, the ECCP is configured through various legal instruments that can be classified into three large systems, namely, the multilateral trading

32 Judgment of the European Court of Justice of 13th December 1973, ECLI:EU:C:1973:165

${ }^{33}$ Opinion of the European Court of Justice of 11 th November 1975 , ECLI:EU:C:1975:145.

${ }^{34}$ However, it has been affirmed that the "new generation" or "deep integration" free trade agreements concluded by the EU with third States go beyond its exclusive competence by including specific aspects of, for example, the reciprocal promotion and protection of the investments, which is why, following Ruling 2/15 of the European Court of Justice in relation to the agreement with Singapore, the European Commission has decided that this entire series of free trade agreements be concluded as "Mixed Agreements", that is, they are jointly signed by the EU and by all its Member States. Some authors, such as Professor Javier Díez-Hochleitner, propose, in order to preserve the exclusive character of the ECCP, "to separate the commitments on investment protection from the free trade agreements, which require the joint signature of the EU and all its Member States and include them in Mixed Agreements that complement the free trade agreements”. Javier Díez-Hochleitner Rodríguez, «La Nueva Política Comercial de la Unión Europea Desborda el Marco de sus Competencias. Comentarios Preliminares al Dictamen 2/15 del TJUE», Revista de Derecho Comunitario Europeo 57 (2017): 429. 
system, whose instruments derive from the membership of the EU and its Member States in the World Trade Organization and the obligation to comply with its legal framework; the conventional bilateral and regional system, through which the EU concludes free trade agreements with third States and trade organizations in order to advance in the abolition of trade barriers to international imports and exports and promote economic growth on the basis of article XXIV of the General Agreement on Tariffs and Trade; and, finally, the autonomous or unilateral system, which includes a wide variety of legal instruments related to tariff policy, export and import regimes, trade defence, and tariff preferences for the least developed countries, within which the European generalized scheme of preferences stands out. Focusing on the bilateral and regional conventional system, that is, all the free trade agreements concluded by the EU with third States, despite the fact that all of them pursue the main objective of abolishing barriers and obstacles to international trade and its liberalization, different nuances regarding its secondary objectives or its content make its formal name vary. Thus, in addition to the free trade per se, the EU has also signed other types of agreements: Economic Partnership Agreements define as asymmetric trade agreements that offer third States (generally with a low level of development such as African, Caribbean and Pacific countries) a franchise of customs duties and quota-free access to the European market. Deep and Wide Scope Free Trade Zones, which must be understood as the trade agreements concluded by the EU with Moldova, Ukraine and Georgia, which depend to a large extent on a gradual legal approximation of these States to the EU's acquis. Finally, Stabilization and Association Agreements with the Western Balkans base on political dialogue with a view to future membership of this series of States in the $\mathrm{EU}^{35}$.

\section{Are these Memorandums of Understanding Free Trade Agreements?}

Although all MoUs signed between China and European Member States foreseen the same provisions, we are going to take a deep look to the $\mathrm{MoU}$ concluded with Italy ${ }^{36}$, as this country has been the first G7 country to

35 Antonio Blanc Altemir, «Introducción: La Unión Europea, adalid del libre comercio ante el neoproteccionismo de la era Trump», in La Unión Europea, Promotora del Libre Comercio: Análisis e Impacto de los Principales Acuerdos Comerciales dir. By Antonio Blanc Altemir (Pamplona: Thomson Reuters Aranzadi, 2020): 20.

${ }^{36}$ Italian Government, «China-Italy Memorandum of Understanding», 2019, Available in: http://www.governo.it/sites/governo.it/files/Memorandum_Italia-Cina_EN.pdf (last accessed: May 5, 2021). 
formally join the BRI and the one that has caused a significant increase in tensions within the EU.

In the preamble, similarities between MoUs and free trade agreements can be found. Both instruments recognize the importance of strengthening their economic, trade and investment relations, in accordance with the objective of sustainable development, thus priming trade matters, although the title of these MoUs do not specify that. It is also usual that both instruments mention regional and multilateral instruments like the United Nations Charter, the 2030 Agenda, the Paris Agreement, the EU-China 2020 Strategic Agenda for Cooperation and the EU Strategy for Connecting Europe and Asia adopted in October 2018. Nevertheless, in every MoU, the parties affirm that the aspiration of said $\mathrm{MoU}$ is to further bilateral practical cooperation. Further practical cooperation in trade matters can entail adopting enforceable measures, thus distancing the nature of these MoUs from its initial conception as soft-law and getting closer to binding international treaties like free trade agreements.

Moreover, if we closely take a look to the content of these MoUs, we will be able to perceive that every one of them contains an article related to trade, entitled "unimpeded trade and investment." In the case of the ChinaItaly MoU, this article states "(...) The Parties reaffirm their shared commitment to free and open trade and investment, to counter excessive macroeconomic imbalances and to oppose unilateralism and protectionism (...) They will promote transparent, non-discriminatory, free and open trade and industrial cooperation, an open procurement, level playing field and respect for intellectual property rights (...)". Making an extensive interpretation of this paragraph, and focusing in the content rather than the format, one could argue that this provision is masking a typical disposition from a free trade agreement, which, again, are governed by International and European Law in force, and constitute an exclusive competence of the EU.

To avoid a violation of EU Law, Member States, such as Italy, have made an effort to ensure that the format of the MoU clarifies its nonbinding nature, using the instrument of soft-law called "Memorandum of Understanding" and terms like "Unimpeded trade and investment", thus not giving the EU the chance to contest and declare this kind of agreements incompatible with EU Law. However, taking into account the content of the $\mathrm{MoU}$ and not its format, a de facto violation, instead of a de jure violation ${ }^{37}$, can be defended, because, although it is a non-binding international

37 In 2017, the Court of Justice of the EU already settled a case in which the nature of the "EU-Turkey action plan" was debated as a political agreement concluded by the European Council (and, therefore, controllable by the Court of Justice) or as an international treaty 
norm, as Van Der Eijk and Pandita Gunavardana affirm, "moving forward in implementing these intentions could not only exacerbate political tensions within the EU but also lead to a violation of Italy's legal obligations as a EU Member State. Although this section (Unimpeded trade and investment) does not explicitly mention the creation of trade or investment agreements, if steps were made in the direction of creating binding intergovernmental agreements that solidify the commitments set out in the Memorandum without the approval of the EU, that would be at odds with EU Law"38.

\section{What can the EU do?}

If, finally, the European Commission, who is in charge of promoting the general interest of the Union and supervising the application of Union Law under the control of the Court of Justice according to article 17.1 of the Treaty on the EU, decides to pay attention to the content of the MoUs signed by its Member States with China and considers that the provisions of these instruments fall within the ECCP and, therefore, are incompatible with EU Law in force, it shall launch an infringement procedure, foreseen in article 258 of the TFEU, which states: "If the Commission considers that a Member State has failed to fulfil an obligation under the Treaties, it shall deliver a reasoned opinion on the matter after giving the State concerned the opportunity to submit its observations. If the State concerned does not comply with the opinion within the period laid down by the Commission, the latter may bring the matter before the Court of Justice of the EU". In other words, through this procedure, the European Commission fulfils its role of ensuring that Member States comply with European legislation in order to harmonize their national Law and international agreements with European Law in force ${ }^{39}$ and the Court of Justice conducts judicial review to monitor the Member States obligations under the legal framework of the $\mathrm{EU}$, as the Commission do not have investigation service ${ }^{40}$.

concluded by the Heads of State (and, therefore, not controllable by the Court of Justice). Finally, without making the nature of this document clear, what the Court affirms is that said document is an agreement signed by the Heads of State and not an agreement signed by the European Council, as they pretended to show, constituting, then, a de facto violation. Judgment of the European Court of Justice of 28th February 2017, ECLI:EU:T:2017:128.

38 Van der Eijk and Pandita Gunavardana, «The Road...».

39 Bezerita, «Infringement...», 701.

40 Tunjica Petrasevic, «Infringement Procedures before the Court of Justice of the EU», Pravni Vjesnik God 29, n. ${ }^{\circ} 1$ (2013): 77. 
Regarding the types of breaches by EU Member States, according to Craig and de Burca, these breaches include the breach of the obligation of sincere cooperation under article 4.3 of the Treaty on the EU, already studied, inadequate implementation of European Law, breaches which interfere with EU external action, as it could be the conclusion of MoUs incompatible with the ECCP, and systemic and persistent breaches of general principles $^{41}$.

The problem with this infringement procedure is the discretion that surrounds it, since it is the European Commission who finally decides what type of violation and against which Member State it will initiate proceedings and send it to the Court, as well as on the timing of these proceedings.

Besides, according to article 259, "before a Member State brings an action against another Member State for an alleged infringement of an obligation under the Treaties, it shall bring the matter before the Commission", so, if, for example, Germany, which strongly opposes to the BRI, wants to declare the incompatibility between the China-Italy MoU and the EU Law in force, at the end, it continuous to be the European Commission the one that declares such incompatibility.

Finally, the article 260 includes the possibility of imposing financial sanctions on a Member State that has failed to implement a judgment in which the European Court of Justice declares the infringement ${ }^{42}$.

Another possible solution applicable to this legal conflict could be for the EU Court of Justice to declare these MoUs incompatible with EU Law, since, according to article 218.11 of the TFEU: "A Member State, the European Parliament, the Council or the Commission may obtain the opinion of the Court of Justice as to whether an agreement envisaged is compatible with the Treaties. Where the opinion of the Court is adverse, the agreement envisaged may not enter into force unless it is amended or the Treaties are revised"43.

${ }^{41}$ Paul Craig and Grainne de Burca, EU law, text, cases and materials (Oxford: Oxford University Press, 2011): 423-424.

42 Article 260 of the TFEU: "If the Court of Justice of the EU finds that a Member State has failed to fulfil an obligation under the Treaties, the State shall be required to take the necessary measures to comply with the judgment of the Court. If the Commission considers that the Member State concerned has not taken the necessary measures to comply with the judgment of the Court, it may bring the case before the Court after giving that State the opportunity to submit its observations. It shall specify the amount of the lump sum or penalty payment to be paid by the Member State concerned which it considers appropriate in the circumstances. If the Court finds that the Member State concerned has not complied with its judgment it may impose a lump sum or penalty payment on it".

43 This article was alleged in the aforementioned case of the "EU-Turkey action plan". If this action plan was concluded by the European Council and not by the Head of the EU Member States, and it finally was an international treaty, this document could have been monitored by the Court. 


\section{Conclusion}

As we have been able to testify, the BRI, understood as the Chinese strategy which aims to gradually develop a global infrastructure through a multitude of investment projects mainly focusing on building transport and energy infrastructure that allows the country to take advantage of the resources and raw materials of third countries, to expand China's influence abroad and to increase economic growth, has reached Europe and China has managed to expand said influence in some Member States of the EU, although others remain reluctant. The way through which China materializes its bilateral trade relations with these Member States has been the MoUs, which, as we have been able to analyse, taking into account their format, are mere political agreements framed in soft-law, not international treaties as defined in the Vienna Convention on the Law of Treaties.

This paper has analysed some of the legal problems that originate these MoUs, such as their collision with Article 4.3 TEU, which foresees sincere cooperation between the EU and its Members States, and the 1974 Council Decision, establishing a consultation procedure for cooperation agreements between Member States and third countries. Furthermore, this paper has studied the possibility that these soft-law instruments also represent a presumed violation of the Common Commercial Policy, which is one of the EU exclusive competences. Taking into account the content of the MoU and not its format, a de facto violation, instead of a de jure violation, can be defended.

To prevent some Member States from violating EU Law by concluding free trade agreements framed in the aforementioned Common Commercial Policy, the European Commission, the main guardian of compliance with European treaties, can initiate an infringement procedure established in articles 258, 259 and 260 of the TFEU. In addition, the EU Court of Justice, according to article 218, can issue an opinion on the incompatibility of these MoUs with EU Law in force. However, the necessary steps have not yet been taken to do so.

Although the aforementioned violation of the Common Commercial Policy may be debatable, what raises no doubt is the weakening of the EU trade and investment power. Traditionally, all trade and investment relations with third countries have been formalized through multilateral free trade agreements concluded by the EU within its Common Commercial Policy and governed by International and European Law. The growing number of bilateral cooperation agreements, here called MoUs, between EU Member States and third States such as China in areas related to trade and investment not only implies a weakening of European integration in these matters, already hit by issues such as Brexit or the consequences of COVID-19, but an increase in Chinese influence in this region. 
While it is true that the EU has always been reluctant to participate in the BRI regionally, and so do countries such as Germany, the truth is that given the incorporation of some of its Member States into the China Initiative, Europe should be able to give a common response to the Chinese challenge. Determining whether this joint EU response should be to accept or to reject the BRI is open to debate, since participation in this Initiative carries economic benefits, but also security risks that are not negligible.

\section{Bibliography}

Alonso, Antonio. «Los intereses de China en Asia Central, Belt and Road», Revista UNISCI 45 (2017): 67-84. DOI: http://dx.doi.org/10.5209/RUNI.57284

Bezerita, Luciana, «Infringement procedure - The case of Romania», Internal Auditing and Risk Management 4, . $^{\circ} 60$ (2020): 70-82.

Blanc Altemir, Antonio, «Introducción: La Unión Europea, adalid del libre comercio ante el neoproteccionismo de la era Trump», in La Unión Europea, Promotora del Libre Comercio: Análisis e Impacto de los Principales Acuerdos Comerciales dir. By Antonio Blanc Altemir (Pamplona: Thomson Reuters Aranzadi, 2020): 23-36.

Busilli, Virginia Soledad, «Belt and Road Initiative (BRI): la iniciativa estratégica de Xi Jinping», Cuadernos de Política Exterior Argentina (Nueva Época) 131 (2020): 69-88.

Craig, Paul and Grainne de Burca, EU law, text, cases and materials. Oxford: Oxford University Press, 2011.

David Arase, «Trends in Southeast Asia. The geopolitics of Xi Jinping's Chinese dream: problems and prospects», ISEAS-Yusof Ishak Institute 15 (2016): 1-30.

De Conti, Bruno, Marina Sequetto Pereira and Daniela Magalhães Prates, «Belt and Road Initiative: A Chinese Marshall plan? », Papel Político 24, n. 2 (2019): 1-15, DOI: https://doi.org/10.11144/Javeriana.papo24-2.bric

Díez-Hochleitner Rodríguez, Javier, «La Nueva Política Comercial de la Unión Europea Desborda el Marco de sus Competencias. Comentarios Preliminares al Dictamen 2/15 del TJUE», Revista de Derecho Comunitario Europeo 57 (2017): 403-429.

Guzman, Andrew T. and Timothy L. Meyer, «International Soft Law», Journal of Legal Analysis 2, n. ${ }^{\circ}$ (2010): 171-225.

Minghao, Zhao, «The Belt and Road Initiative and its Implications for ChinaEurope Relations», International Spectator: Italian Journal of International Affairs 51, n. ${ }^{\circ} 4$ (2016): 109-118, DOI: 10.1080/03932729.2016.1235819

Misiągiewicz, Justyna, and Marcin Misiągiewicz, «China's "One Belt, One Road" initiative - the perspective of the EU», Annales Universitatis Mariae Curie-Skłodowska, Sectio K - Politologia 23, n. ${ }^{\circ} 1$ (2016): 33-42, DOI:10.17951/k.2016.23.1.33.

Pagán Sánchez, Antonio José, «Internal tensions and economic opportunities: explaining the heterogeneous stance of EU Member States towards the Belt and 
Road Initiative», Revista Electrónica de Estudios Internacionales 40 (2020): 1-18. DOI: $10.17103 /$ reei.40.13

Petrasevic, Tunjica, «Infringement Procedures before the Court of Justice of the EU», Pravni Vjesnik God 29, n. ${ }^{\circ} 1$ (2013): 77-98.

Ríos, Xulio. «The Belt and Road Initiative: An Opportunity for Spain», Sinología Hispánica, China Studies Review 6, n. 1 (2018): 157-176.

Van der Eijk, Femke and Angela Pandita Gunavardana, 25th June, 2019, «The

Road that divided the EU: Italy joins China's Belt and Road Initiative», European Law Blog. Available in, https://europeanlawblog.eu/2019/06/25/the-roadthat-divided-the-eu-italy-joins-chinas-belt-and-road-initiative/

Vangeli, Anastas, «China's Engagement with the Sixteen Countries of Central, East and Southeast Europe under the Belt and Road Initiative», China and World Economy 25, n. 5 (2017): 101-124, DOI: 10.1111/cwe.12216

\section{Sobre la autora}

Carmen Martínez San Millán es contratada predoctoral por la Junta de Castilla y León en el área de Derecho Internacional Público y Relaciones Internacionales de la Universidad de Valladolid. Es doble graduada en Derecho y Administración y Dirección de Empresas y cuenta con un Máster en Altos Estudios Internacionales y Europeos por la Universidad de Granada. En el curso de sus estudios de doctorado ha realizado una estancia de investigación en el Max Planck Institute for Comparative Public Law and International Law y ha impartido clases en un Máster de Relaciones Internacionales y Estudios Asiáticos de la Universidad de Valladolid. Asimismo, es miembro de la Asociación de Profesores de Derecho Internacional y Relaciones Internacionales, del Observatorio de Estudios Africanos de la Universidad de Valladolid y del Observatorio de Derechos Humanos de la Universidad de Valladolid, así como de Asia Power Watch. Su línea de investigación principal es la tutela de los derechos laborales fundamentales en el comercio internacional, aunque cuenta con publicaciones sobre el comercio ilícito de coltán o el espacio de libertad, seguridad y justicia de la Unión Europea.

\section{About the author}

Carmen Martínez San Millán is a PhD candidate, employed by the Junta de Castilla y León in the area of Public International Law and International Relations at the University of Valladolid. She has a double degree in Law and Business Administration and has a Master's Degree in Advanced International and European Studies from the University of Gra- 
nada. In the course of her doctoral studies, she has completed a research stay at the Max Planck Institute for Comparative Public Law and International Law and has given lessons at a Master's degree in International Relations and Asian Studies at the University of Valladolid. Likewise, she is a member of the Association of Professors of International Law and International Relations, of the Observatory of African Studies of the University of Valladolid and of the Observatory of Human Rights of the University of Valladolid, as well as of Asia Power Watch Her current research interests is the protection of core labour rights in international trade, although she has publications on the illicit trade of coltan or the area of freedom, security and justice of the European Union. 


\section{Derechos de autor}

Los derechos de autor (para la distribución, comunicación pública, reproducción e inclusión en bases de datos de indexación y repositorios institucionales) de esta publicación (Cuadernos Europeos de Deusto, CED) pertenecen a la editorial Universidad de Deusto. El acceso al contenido digital de cualquier número de Cuadernos Europeos de Deusto es gratuito inmediatamente después de su publicación. Los trabajos podrán leerse, descargarse, copiar y difundir en cualquier medio sin fines comerciales y según lo previsto por la ley; sin la previa autorización de la Editorial (Universidad de Deusto) o el autor. Así mismo, los trabajos editados en CED pueden ser publicados con posterioridad en otros medios o revistas, siempre que el autor indique con claridad y en la primera nota a pie de página que el trabajo se publicó por primera vez en CED, con indicación del número, año, páginas y DOI (si procede). Cualquier otro uso de su contenido en cualquier medio o formato, ahora conocido o desarrollado en el futuro, requiere el permiso previo por escrito del titular de los derechos de autor.

\section{Copyright}

Copyright (for distribution, public communication, reproduction and inclusion in indexation databases and institutional repositories) of this publication (Cuadernos Europeos de Deusto, CED) belongs to the publisher University of Deusto. Access to the digital content of any Issue of Cuadernos Europeos de Deusto is free upon its publication. The content can be read, downloaded, copied, and distributed freely in any medium only for non-commercial purposes and in accordance with any applicable copyright legislation, without prior permission from the copyright holder (University of Deusto) or the author. Thus, the content of CED can be subsequently published in other media or journals, as long as the author clearly indicates in the first footnote that the work was published in CED for the first time, indicating the Issue number, year, pages, and DOI (if applicable). Any other use of its content in any medium or format, now known or developed in the future, requires prior written permission of the copyright holder. 